\title{
The role of the European Union on immigration - An anthropological approach to the treaties that have been carried out in Europe in order to manage diversity
}

\author{
Carmen Clara Bravo Torres ${ }^{1}$ \\ ${ }^{1}$ Universidad de Granada, Granada, Spain \\ Received: 13 February 2019/Accepted: 10 July 2019
}

\begin{abstract}
Migrations are a global phenomenon that have prevailed throughout history. In recent decades there has been a need to control every person who enters and leaves the borders of a country. This fact can be observed in the European Union where in recent years the migratory phenomenon has appreciated as a problem. This institution carries out different measures in order to manage this diversity within its borders. However, these agreements are not adapted to the different contexts and are not carried out by all the countries that comprise this institution. In spite of all this, the discourse used by the European Union promotes the European identity in front of the rest, differentiating those considered others. These others are differentiated primarily by their nationality although from the discourse analysis, an economic factor can be observed. These themes will be studied in this paper, which will allow us to understand what treaties have been established in the European Union regarding migration and how diversity is managed from them.
\end{abstract}

Key words: European Union, Europeanization, Immigration and International Relations

\section{Introduction}

To understand this work, we should start from the idea that we are in a globalized world where transnational migrations are constant. These migrations have given rise to us being in a society characterized by the exchange of customs and languages. Depending on the context, we find different changes that have been of great importance for the case studied - the European Union. An example is Spain. This country has gone from being mainly a country that emits migrants, to being a recipient of a large number of people of different nationalities.

This situation has led to policies, laws, and different actions being challenged and reformulated to fit the current context but we should keep in mind that the migratory policies of a given country are governed by a series of norms and conventions that rule its usefulness. In the first place, it is important to highlight the competencies of the European Union, and then of the country studied. In this case, the Spanish Constitution, which is adapted to the European Union. Taking into account both aspects, we have in mind the International Treaties that the country has signed and ratified, then the laws or regulations with the rank of law and, finally, the regulations and collective agreements 
(as for example in the field of employment). Therefore, it is interesting to know what role this institution plays in the current migratory situation, with special emphasis on the processes of otherness that it manifests. A qualitative methodology has been carried out mainly for the accomplishment of this research, characterized by the bibliographical revision of experts both in migration issues and the role of the European Union in the international sphere. Among them, we highlight Barbé (2010, 2014), Olmos (2009) and Palomares Lerma (2010). It is necessary to be aware of the great dimension of the topics that are intended to be addressed in this document. Therefore, this work has been divided into a series of sections where different conventions have been treated in terms of policies of immigration, European councils, and the role of European identity over the rest. Treaties have been chosen since these are European mandates that have been determining the integration of the migrants in the European Union.

\section{European immigration policies}

Firstly, we must assume that the migration phenomenon is not a novel situation for the European Union. Migrations are a fundamental element of European identity. Since its formation, the European Union has been characterized by both emigration and immigration. Before the creation of the European Union, there already was a considerable flow of people between the different States, motivated primarily by the search for work (Cabré, Domingo 2002). From the Second World War, the need for labour increased. This led to the implementation of a series of measures to accommodate workers from other European States. This flow of people has been constant. Throughout history, some nationalities have predominated over others, since large numbers of people have been moving both within Europe and crossing their borders in times of economic recession and wars. At present, the migratory flow has been increasing, although a large number of people are not taken into account because the figures of migrants in Europe do not fit the reality.

While it is difficult to record all migratory flows, it should be noted that since the last century there is a greater need to restrict, control, and measure all issues that cross state borders, especially those that delimit the European Union (Moeykens 2013). An example of this is observed in Spain, when months before entering the European community the country was obliged to make the first regulation on the Rights and Duties of foreigners (Organic Law 7/1985, of July 1, on rights and freedoms of foreigners in Spain). From this moment, Spain has been influenced by the European Union and has a long legislative path around the migratory issue, since it is characterized by a constant change and a continuous redefinition. But do the laws agree with the existing reality? What is the purpose of these laws?

It is necessary to start from the idea that, as we will see later, in the development of the different Treaties that have tried to regulate immigration, the European Union is increasingly placing greater emphasis on immigration within its borders. This has been implemented since the Treaty of Lisbon, where the sovereignty of States has begun to be questioned as asylum or police cooperation have been regulated by the European Union. However, "many of the rules adopted in the field of immigration constitute what we call minimum standards, that is, they leave a wide margin of discretion to the States in terms of their development" ${ }^{1}$ (Barbé 2010, p. 134). These policies appear in relation to the aspects of "integration" where the European Union has indicated what they refer to as good practices. These are a set of guidelines covering how States should act towards migrants entering the territory. However, these guidelines are very general and rarely followed in practice.

Three European states decided not to adjust to the regulation of migration imposed by the European Union. They carry out only those policies that interested him. These countries are Denmark, Ireland, and the United Kingdom (European Union 2015). From such distinctions we find how Europe does not present solid policies and is already divided

\footnotetext{
${ }^{1}$ Spanish original: "muchas de las normas que se adoptan en materia de inmigración constituyen lo que llamamos normas de contenido mínimo, es decir, que dejan un amplio margen de discrecionalidad a los Estados en cuanto a su desarrollo".
} 
in different aspects. This challenges its representation as a unique institution. However, these general policies have been of great importance, especially those carried out with regard to border control, since the others have made it possible for the Member States to be more flexible in their implementation. Regarding border control, we should highlight the Schengen agreement, signed in 1985; which indicates the removal of internal borders. From this agreement, we can observe the relevance that the European Union to freedom of movement between certain countries. From this agreement, we can observe the relevance that the European Union brings to the freedom of movement between certain countries. In those cases where this free movement does not exist, it is necessary to emphasize the use of a visa, which will vary according to the country that you belong to and the stay in the determined country will require a series of permits. In the case of Spain, the residence permit and work permit for a certain economic amount are required, such as for researchers or "circular migrants" (migrant temporary workers). If they do not meet any of the requirements indicated for these types of migrations, their administrative status is considered irregular, despite spending time in Spain working and trying to legalize their situation. The only opportunity is to return to their country and from the so-called contingencies to be contracted by the State from the country of origin. From this fact, we can appreciate the importance of certain groups determined by their permission stay in a particular country.

In spite of the different policies established, which will be developed a posteriori, we must highlight that when there are laws specifically aimed at foreign people, such as immigration law, we are facing a situation where we differentiate us from the considered other. This influences which social policies get implemented. Not all policies are aimed at all people, only those that meet a number of conditions, such as the administrative situation of the subject in the host country. An example of this can be appreciated when, on 7 March 2016, the European Union entered into an agreement with Turkey where the expulsion of refugees from Europe is agreed, transferring them to Turkey, regardless of their country of origin.

From such policies, as here noted, we can see that the humanitarian character is not present in its measures since it is returning people fleeing for war reasons to another country. Although migration is considered as a right (Moeykens 2013), we find a large number of restrictions. In the case of the European Union, we observe how economic aspects have prevailed since its inception, relegating social aspects to a lower priority. For the European Union, what matters is the economy; it encourages external mobility but only to those within its borders. There is now a concern for the protection of the migrant, although this protection is based on the quest to obtain the maximum yield of these subjects. To this, it should be added that in the case of Spain the policies that are established are restorative since it has intervened when the error is already made and not preventive, as should be established. At present, we are dealing with this situation with regard to refugees, since the measures are being implemented based on the complex situation, without taking into account each individual who is being deported to another country. Situations like the one that is happening weaken the positioning of the European Union as an institution in the face of established international relations. A clear example is seen with refugees and since the wreck in Lampedusa. That is to say, "the prestige of the EU is partly conditioned by how it manages the challenge of migration. In this regard, the tragedy of the wreck in Lampedusa in October 2013 showed how far the EU is having instruments to respond effectively to irregular migration." ${ }^{2}$ (Barbé 2014, p. 132).

Thus, we must take into account that we are faced with an institution based on economic aspects but whose reputation is influenced according to its management of different problems, as as the migratory flow. For this reason, in order to understand more clearly what role the European Union plays in immigration, in the following section we will analyse the treaties carried out since these set out the objectives of the European Union.

\footnotetext{
${ }^{2}$ Spanish original: "El prestigio de la UE está en parte condicionado por cómo gestiona el reto de la migración. En este sentido, la tragedia del naufragio en Lampedusa, en octubre de 2013, puso de manifiesto cuán lejos está la UE de disponer de unos instrumentos que le permitan responder de forma eficaz a la migración irregular."
} 


\subsection{Treaties by the European Union}

This paper alludes to treaties from the area of justice, freedom, and security since it is the space that manages borders and mobility of citizens. Based on different treaties carried out in this area, the greater integration of States has been sought to participate as a single institution. However, the lack of consensus among countries has led to their role being questioned as a single institution in the international sphere. There are a number of challenges to the creation of a common migration policy since it is a policy shared among member states.

Firstly, in 1985, the need for free control of persons between the borders of the countries of the Member States was proclaimed, being a priority of cooperation in matters of justice, freedom, and security. The Schengen space was created but until 1995 it did not enter into force. Subsequently, in the Maastricht Treaty for the first time, reference is made to cooperation and the creation of an area of freedom, security, and justice. In addition, this treaty began to promote social aspects such as humanitarian aid. That is to say, "from Maastricht, all treaties reiterate that the EU will uphold and promote its values and interests, and it will contribute to the protection of its citizens, contribute to peace, security, sustainable development of the planet, solidarity and mutual respect among peoples, free trade and the eradication of poverty, the protection of human rights, respect for and development of international law and the principles of the Charter of the United Nations" 3 (Palomares Lerma 2010).

Nevertheless, we have to highlight to the Maastricht Treaty for its evolution of migration policies since this treaty was for intergovernmental cooperation but a posteriori this fact changed with the communitarization in all aspects except in the police and judicial cooperation in criminal matters (Barbé 2014).

Subsequent to this treaty we find the Treaty of Amsterdam, where "a very significant step was taken in integrating migration policy to the first community pillar; which allowed the extension of the ordinary legislative procedure in most matters, with the consequent participation of Parliament as co-legislator with the Council" 4 (Barbé 2014, p. 133). However, as explained above, the three aforementioned States decided to join only those measures that they considered appropriate. From that point on, the European Union had competence in terms of entry and residence, issuance of long-stay visas and residence permits; the residence of illegal immigrants, including repatriation and the conditions under which third-country nationals legally resident in one Member State may reside in another Member State.

Subsequent to this treaty, the current Treaty of Lisbon, "advocates the creation of a common migration policy. The Treaty led to the abolition of the system of pillars and the application of the ordinary legislative procedure in more areas of cooperation, including labour migration policy" 5 (Barbé 2014, p. 133). The Treaty sought the consolidation of a secure Union, tackling both issues of immigration as judicial cooperation and police (Palomares Lerma 2010). Since the Treaty of Lisbon, common visa policies and other residence permits have been adopted, such as controls at the external borders, elimination of controls irrespective of nationality within internal borders, fight against trafficking in human beings, repatriation issues, and exclusion. From the Lisbon Treaty onwards, "the Spanish Presidency of the European Union during the first half of 2010 set out the following objectives in the area of external action: Consolidating a Safer Union for its citizens, tackling together the challenge of Immigration and building a shared space for judicial and police cooperation" 6 (Palomares Lerma 2010).

\footnotetext{
${ }^{3}$ Spanish original: "Desde Maastricht, todos los tratados reiteran que la UE afirmará y promoverá sus valores e intereses y contribuirá a la protección de sus ciudadanos, contribuirá a la paz, seguridad, desarrollo sostenible del planeta, solidaridad y respeto mutuo entre los pueblos, el libre comercio y justo, la erradicación de la pobreza, la protección de los derechos humanos, el respeto y desarrollo del Derecho Internacional y los principios de la Carta de Naciones Unidas".

${ }^{4}$ Spanish original: "se dio un paso muy significativo al integrarse la política de migración al primer pilar comunitario; lo cual permitió la extensión del procedimiento legislativo ordinario en la mayoría de materias, con la consiguiente participación del Parlamento como colegislador junto al Consejo"

${ }^{5}$ Spanish original: "aboga por la creación de una política de migración común. El Tratado condujo a la abolición del sistema de pilares y la aplicación del procedimiento legislativo ordinario en más áreas de cooperación, incluyendo la política de migración laboral".

${ }^{6}$ Spanish original: "La presidencia española de la Unión Europea durante el primer semestre de 2010
} 
In addition to the different treaties carried out, agreements and conventions have been enacted regarding the management of the migratory flow. Among them is the Dublin Convention. Based on this agreement, it established that each member country is responsible for managing and studying the different asylum applications. This is done so that there is only one request and it will not be in the country of preference. It can be requested in the country where you have relatives or in the country of arrival. This agreement was signed in 1990 and subsequently ratified by its member states. It was updated in 2003 and in 2013. At present this agreement is not working since the main weight falls on the countries of entry; therefore, the situation is disproportionate. Just as refugee rights are currently being violated since the established laws are not being carried out, mainly only the country of arrival is being taken into account, and family ties and accepted requests are not taken into account. The European Union is failing in this aspect and should look for proposals and alternatives to correct the bad management of the migratory flows that it is carrying out. Besides, it should be noted that with the approval of convention Stockholm (2009) immigration and asylum policies are strengthened towards neighbouring countries.

Additionally, in terms of integration, a number of multi-annual programs have been carried out through European Councils that set targets over a period of five years, as the Treaties provide for little regulation (Barbé 2014). For this research we have studied the Councils in recent years, from 2009 to 2017. We have studied the number of councils where the European Union talked about the migrations, in what way, and what perception reflects the different subjects. This last aspect will be developed in the next section where we will show the image that the European Union transmits of immigrants, migrants, and refugees.

During these six years, 25 councils have mentioned the migratory phenomenon. At some periods, the topic was barely touched, at others it was the focus of the councils. In 2010 and 2011, all the councils talk about the migratory phenomenon. In these years, the importance of the integration of irregular immigrants is pointed out. In addition, these councils emphasize the importance of foreign relations. Events in the Mediterranean and in Libya stand out. In 2013 and 2014, the councils talked about the need for jobs for immigrants, without specifying their administrative situation in the country of arrival. They also highlight the importance of external relations to control and manage borders. In 2015, these councils emphasized the fight against terrorism, stressing the importance of border control. This last year, all the councils made mention of the migratory phenomenon, emphasizing the cooperation between the different countries and the European Union. They also highlight the need for counter-terrorism and the need to prevent illegal immigration. Thus, based on the analysis of these councils, there is talk of integration, but they do not indicate measures to achieve it. They focus on controlling, managing, and monitoring all those who cross European borders, with the aim of economic profitability, since the emphasis is only on integration from employment. In the Europe 2020 strategy, with regard to European policies, the immigrant only appears once, and in the Green Paper emphasis is placed on labour immigration and strategies are sought for maximum economic gains, in addition to the facilities that are given to circular immigrants.

Therefore, we can observe the importance given to the economic aspects of immigration policies, as it looks at their control and profitability, instead of taking into account other essential factors such as the need for immigrants with respect to the aging of the population. But as we can see through circular migrations, not only do European policies play an important role in migration, but the countries that sign agreements with the European Union facilitate the movement of these people. This can be seen from the acceptance of Turkey regarding the reception of immigrants. It is therefore interesting to consider which aspects are taken into account in neighbourhood policies. In line with the idea proposed by the European Union, it is necessary to cooperate with the country of origin in migration policies, as this will lead to better management.

planteó los siguientes objetivos en el ámbito de la acción exterior: Consolidar una Unión más segura para sus ciudadanos, afrontando conjuntamente el reto de la inmigración y construyendo un espacio compartido de cooperación judicial y policial". 
Firstly, we must point out that border management in the European Union is managed by FRONTEX (European Agency for Operational Cooperation at the External Borders of the member states of the European Union) and the corresponding border guard services in third countries. Despite the designation of this border, account should be taken of the policies entered into with these third countries and that "the European Union has chosen its proximity countries, since it is these countries that generate more migration flows into the Union"7 (Barbé 2014, p. 132). But in order to be able to understand the neighbourhood policies that are carried out, we should take into account the designations that are used to name the subjects. For this reason, the next section will analyze how, based on what was studied, the subjects studied are designated and constructed as different, in order to deepen the neighbourhood policies in the future. These policies have benefits in terms of economic, social, political, and cultural aspects. Primarily they are based on the strategic associations in search of greater economic growth in both countries.

\subsection{Regular immigration / irregular immigration / asylum}

Designations for naming a subject have great relevance for the group that represents him as the represented, since "the denominations represent the most primary form of description. So that the simple fact of 'how to call' things, people, or phenomena can help the treatment they receive" 8 (Olmos 2009, p. 245). Thus, from the denominations we represent the rest of the population by which we establish differences with those that we consider the "others" different from "we". This fact we observe in speeches and in laws and regulations at state level. Common examples include the denomination of immigrant, illegal or irregular immigrant, foreigner, or refugee. "The creation of a new legal instrument on immigration leads to the emergence of new categories of subjects; To foreign / national distinction, is added from European foreign / non-EU immigrants and within the latter establishes an even lower, illegal or irregular classification." ${ }^{9}$ (Briceño 2004, p. 205).

The terms mentioned play a fundamental role in the naming of others, so they must be explained in detail. But, it is necessary to start from the difference of foreigner / immigrant. A foreigner is one who does not have Spanish nationality. However, immigrants are the majority, if characterized by a relative change of residence in a given time (Castelo 2005). Therefore, no human being is illegal or legal, but its administrative situation in the country of origin may be regulated or not.

With regard to irregular immigration, the European Union has given it great importance as there is an interest in fighting illegal immigration because they are perceived in a negative way. These subjects are constructed as an other different from us, to distance ourselves even more from them and to justify the measures taken. That is why border management and the different preventive measures are important since most of the collaboration with countries neighbouring have been to reduce clandestine immigration flows. It is important to highlight how readmission agreements have been implemented: "The readmission agreements are formally international agreements signed by the European Union and a third State. It is an agreement with a highly technical content that specifies the assumptions and procedures under which the readmission of an irregular immigrant in his country of origin is foreseen." ${ }^{10}$ (Barbé 2010, p. 136). Although these readmissions are a fundamental right.

\footnotetext{
${ }^{7}$ Spanish original: "la UE ha optado por los países de su proximidad, dado que son estos países los que generan más flujos migratorios hacia la Unión".

${ }^{8}$ Spanish original: "las normalizaciones/denominaciones suponen la forma más primaria de descripción, de tal manera que el simple hecho de 'cómo llamar' a las cosas, personas o fenómenos ... puede ayudar al trato que reciben".

${ }^{9}$ Spanish original: "De la creación de un nuevo instrumento jurídico en materia de inmigración se deriva la emergencia de nuevas categorías de sujeto; a la distinción extranjero/nacional, se añade de extranjero europeo/ inmigrantes no comunitarios y dentro de esta última se establece una clasificación aun inferior, ilegal o irregular".

${ }^{10}$ Spanish original: "Los acuerdos de readmisión son formalmente acuerdos internacionales firmados por la Unión Europea y un tercer Estado. Se trata de un acuerdo con un contenido altamente técnico en el que se especifican los supuestos y procedimientos bajo los cuales se prevé la readmisión de un inmigrante irregular en su país de origen."
} 
This is a very costly situation, so the European Union has promoted specific incentives, such as the facilitation of obtaining visas. This is a step towards the liberalization of visas. However, these measures are not taken together with the countries closest to Spain in the Mediterranean neighbourhood. We can therefore highlight how, in the area of irregular immigration, the European Union has agreements with certain countries for readmission, but based on clearly Europeanising measures linked to security (Barbé 2010).

With regard to regular migration, it should be noted that it is not a global priority for the European Union. However, it does play an important role in terms of employment since different agreements are in place to allow regular migration. "It is important to note that bilateral cooperation has been developed between some Member States of the European Union and Morocco in order to strengthen the temporary recruitment of Moroccan nationals in EU countries"11 (Barbé 2010, p. 142). This fact can also be seen with the creation of the Green Paper, which focuses on labour migration and economic migration. For this reason, workers are differentiated between skilled workers, seasonal workers, paid interns, self-employed, and workers transferred by multinationals (Bazzaco 2008). However, the European Union does not focus on those migrants whose administrative situation in the country is not regulated.

Unlike the two aspects mentioned above, cooperation in the field of asylum between European Union and other countries has been based on the protection of refugees from the 1951 Geneva Convention on the Status of Refugees. This Convention not only takes into account refugees, but also those who, despite not being refugee, are at risk of persecution in their country. According to Barbé (2014), one of the key elements established in this Geneva regime was the principle of non-refoulement. But this seems not to be very clear since in the case of Turkey and Syria, we are witnessing this principle not being fulfilled. To these breaches must be added the lack of coherence and agreement between the different countries of the European Union with its neighbours since contexts of this institution are different and each of them has interests and opposing thoughts regarding policies established with neighbouring countries.

So that, "in an increasingly interdependent world, the European Union is working for economic and commercial globalization, which will benefit everyone, as well as the search for political stability in the world. By carrying out cooperation and assistance, the Union contributes to the achievement of the objectives of peace, development and security for all. It is necessary to remember that we are in a multipolar world and that, under these circumstances of international society, the states of the European Union can only defend their values, objectives and interests if they speak with one voice in the world" 12 (Palomares Lerma 2010, p. 20).

But each context is unique and there is no clear consensus among different states to represent as a single institution. This can lead to great havoc at the social level. However, they are all represented as Europe, with a common identity which they want to claim.

\section{Europe and the Others}

This Europeanization is represented in the established policies and in the catalogues of each one of the individuals. Therefore, it is necessary to emphasize that "we believe that to identify, to call, to denominate to some people 'immigrants' and other 'foreigners' influences in the way in which we perceive them because one designation and another they have loads of different values" ${ }^{13}$ (Olmos 2009, p. 71). Thus, foreigner does not

\footnotetext{
${ }^{11}$ Spanish original: "Es importante destacar que se ha venido desarrollando cooperación bilateral entre algunos Estados Miembros de la Unión Europea y Marruecos a fin de fortalecer el reclutamiento con carácter temporal de nacionales marroquís en países de la U.E.".

${ }^{12}$ Spanish original: "En un mundo cada vez más interdependiente, la UE trabaja por una globalización económica y comercial más justa, que redunde en beneficio de todos, y también en la búsqueda de estabilidad política en el mundo. Realizando labores de cooperación y ayuda, la Unión contribuye a alcanzar los objetivos de paz, desarrollo y seguridad para todos. Es necesario recordar que nos encontramos en un mundo multipolar y que, bajo estas circunstancias de la sociedad internacional, los Estados de la Unión Europea sólo pueden defender sus valores, objetivos e intereses si hablan con una sola voz en el mundo"

${ }^{13}$ Spanish original: “creemos que identificar, llamar, denominar a algunas personas 'inmigrantes' y a otras 'extranjeros' influye en la forma en que las percibimos porque una designación y otra tienen cargas
} 
have the same meaning as immigrant since foreigner refers to both those who comply with the regulations established in the laws of foreigners, as well as those belonging to the European Union and those who have a specific economic rent. The established discourse is of great relevance since from the term that we use to denominate the people we are associating the group with different visions of ethnic elements, motivations, and determined opportunities (García et al. 2008). We are in a country belonging to the European Community where concrete policies are attributed similar to the rest of this community, even though the contexts are totally different. These policies influence the public discourse both outside and within the system. Therefore, this fact has relevant consequences at the social level.

Regarding terminology, it is important to note that despite of the many different words and policies that are used for people who arrive in Spain, those who leave the country are all referred to as 'emigrants'. This is regardless of whether their destination is inside or outside of the European Union, and regardless of the administrative situation of the country. Through this, we appreciate how the legislation itself shows the importance of being considered European, discriminating and considering different people who do not belong to that community. Therefore, "It is necessary to understand the migratory policy in Spain as a consequence of the European dictates, under the ideology of the construction of the "Fortress Europe", which explains many of the contradictory discourses and policy reactions developed in this country" (Agrela, Gil 2004, p. 6). Continuing with the Spanish context and with most European countries; we are faced with dynamic contexts, which are not taken into account in many of the policies or in the social discourse because subjects are categorized for ethnic elements, irrespective of their position in the European country studied. This fact is observed with young people called second generation (Barquín 2009, Massot 2005, Moreno 2002). All these attributions can have great consequences in the collective social imaginary as in the identity of each of the subjects. Therefore, the policies put in place by the European Union and the terminology used can contribute significantly to the construction of the other, thus reinforcing the European identity. Thus, it should be emphasized that this identity, like any process of otherness and identification, arises from essentialist categories typical of a Eurocentric view.

\section{Final Reflections}

The migration phenomenon has always been an issue that has been present in the European Union. However, currently immigration has been problematized and this institution is not able to cope with this flow of people as it does not present a clear and real distinction in terms of the legislative figure represented by the different subjects. That is, it is clear who is a foreigner and a community citizen, but there is no distinction between immigrant and refugee. However, in treaties and agreements a differentiation is established, although not clear, since they mention that said measures are aimed at a specific group, such as refugees. From the established treaties, the right to emigrate, solidarity, and the management and importance of asylum applications stand out. However, we find that it is not being fulfilled and at present, the European Union does not have a common asylum or immigration policy. Only a series of agreements with different countries are established. These are scarce and do not cover the existing problems.

The current policies are restrictive and are based on border control, promoting differentiation with respect to the "others". Although such differences will vary according to the country and the framed categories, mainly based on ethnic and economic reasons. These are justified by the administrative situation in the country of destination. With regard to irregular immigration, the European Union focuses on Europeanization, while regular immigration is based on rules and agreements between different countries. As far as asylum applications are concerned, they prevail in international standards that although in spite of being scarce, are not being met.

From the analysis of the treaties, agreements, and advice made, the need to control borders, the externalization of resources with respect to the management of migratory flows, and the criminalization granted to some people is observed. The measures that

de valores distintos"

REGION: Volume 6, Number 1, 2019 
the European Union is carrying out, the political discourse, and the role of the media have great importance because it is not having a humanitarian character in this situation, producing a boom in political parties of far right where the racism and the nationalism are encouraged. We must be aware of the current situation of the European Union and of the influence that its actions have at a social level.

\section{References}

Agrela B, Gil S (2004) Constructing Otherness. The Management of migration and diversity in the Spanish context. Migration: European Journal of International Migration and Ethnic Relations 43

Barbé E (2010) La Unión Europea más allá de sus fronteras. ¿Hacia la transformación del Mediterráneo y Europa Oriental? Tecnos, Madrid

Barbé E (2014) La Unión Europea en las Relaciones Internacionales. Tecnos, Madrid

Barquín A (2009) ¿De dónde son los hijos de los inmigrantes? La construcción de la identidad y la escuela. Educar 44: 81-96

Bazzaco E (2008) La Unión Europea frente a los procesos migratorios: lejos de una política integral. Papers 104: 57-65

Briceño Y (2004) Inmigración, exclusión y construcción de la alteridad. La figura del inmigrante en el contexto español. In: Mato D (ed), Políticas de ciudadanía y sociedad civil en tiempos de globalización. faces, Universidad de Venezuela, Caracas

Cabré A, Domingo A (2002) Flujos migratorios hacia Europa: actualidad y perspectivas. Arbor 172: 325-344. CrossRef.

Castelo G (2005) Logros y Retos del frente Indígena Oaxaqueño Binacional: una organización para el futuro de los migrantes indígenas. Tesis licenciatura. universidad de las américas públicas

European Union (2015) European Union Law: Justice, freedom and security. https://eurlex.europa.eu/summary/chapter/justice_freedom_security.html?root_default=SUM_1_CODED $\% 3 \mathrm{D} 23$

García FJ, Rubio M, Bouachra O (2008) Población inmigrante en y escuela en España: Un balance de investigación. Revista de educación 345: 23-60

Massot I (2005) Hijas e hijos de inmigrantes: la mal llamada segunda generación. Abaco: Revista de cultura y ciencias sociales 43: 67-78

Moeykens E (2013) El derecho a migrar como un Derecho Universal: los derechos del migrante en el Estado democrático de Derecho. X Jornadas de Sociología. Facultad de Ciencias Sociales. Universidad de Buenos Aires, Buenos Aires

Moreno P (2002) Reflexiones en torno a la segunda generación de inmigrantes y la construcción de la identidad. Ofrim suplementos 10: 9-30

Olmos A (2009) La población inmigrante extranjera y la construcción de la diferencia. Discursos de alteridad en el sistema educativo andaluz. Doctoral thesis. Universidad de Granada

Palomares Lerma G (2010) La Unión Europea en la sociedad internacional. In: Estudios de Política Exterior (ed), Cuadernos pedagógicos sobre la Unión Europea. La acción exterior de la Unión Europea. Estudios de Política Exterior, Madrid, 3-16 